\title{
Inhibition of Listeria monocytogenes by bacteriocin-producing Bacillus velezensis
}

\section{isolated from silage}

\section{Inibição de Listeria monocytogenes por Bacillus velezensis produtor de bacteriocina isolado de silagem}

Inhibición de Listeria monocytogenes por Bacillus velezensis el productor de bacteriocina aislado del ensilaje

Laura Bonato Alves Oliveira

ORCID: https://orcid.org/0000-0003-0827-8886 Faculdade de Ciências Médicas e da Saúde de Juiz de Fora, Brazil E-mail: laurabonato.oliveira@hotmail.com

Yasmin Neves Vieira Sabino

ORCID: https://orcid.org/0000-0001-6489-374X Universidade Federal de Viçosa, Brazil

E-mail: yasmin.nvs@hotmail.com

Marlon do Valle Barroso

ORCID: https://orcid.org/0000-0003-0746-8928 Faculdade de Medicina de São José do Rio Preto, Brazil E-mail: marlonvalle.bio@hotmail.com

Ranaíla Kely Ferreira

ORCID: https://orcid.org/0000-0002-2055-0523

Universidade Federal de Juiz de Fora, Brazil

E-mail: ranaila@hotmail.com

Junior Cesar Fernandes Lima

ORCID: https://orcid.org/0000-0001-7982-9644 Empresa Brasileira de Pesquisa Agropecuária Gado de Leite, Brazil E-mail: junior.lima@embrapa.br

Pedro Braga Arcuri

ORCID: https://orcid.org/0000-0003-1294-4730 Empresa Brasileira de Pesquisa Agropecuária Gado de Leite, Brazil E-mail: pedro.arcuri@embrapa.br

Jailton da Costa Carneiro

ORCID https://orcid.org/0000-0001-6030-4194 Empresa Brasileira de Pesquisa Agropecuária Gado de Leite, Brazil E-mail: jailton.carneiro@embrapa.br

Ricardo José de Mendonça ORCID: http://orcid.org/0000-0002-6957-3363 Universidade Federal do Triângulo Mineiro, Brazil E-mail: ricardo.mendonca@uftm.edu.br João Batista Ribeiro

ORCID: https://orcid.org/0000-0003-1502-4796 Empresa Brasileira de Pesquisa Agropecuária Gado de Leite, Brazil E-mail: joao-batista.ribeiro@embrapa.br

Alessandra Barbosa Ferreira-Machado

ORCID: https://orcid.org/0000-0003-3972-7576

Universidade Federal de Juiz de Fora, Brazil E-mail: alessandra.machado@ufff.br

Aline Dias Paiva

ORCID: https://orcid.org/0000-0003-4234-8892 Universidade Federal do Triângulo Mineiro, Brazil E-mail: aline.paiva@uftm.edu.br

\begin{abstract}
The aim of this study was to investigate the production of anti-Listeria bacteriocins by naturally occurring bacteria on silage and to characterize the most promising bacteriocin. The production of bacteriocins was evaluated by the spoton-lawn method. The presence of interfering factors and the sensitivity to proteinase $\mathrm{K}$ were analyzed. The spectrum of activity was determined and the most promising bacteriocin-producing isolate was identified, being selected for the subsequent experiments. The antimicrobial peptide was extracted, analyzed regarding temperature and $\mathrm{pH}$ sensitivities, and purified. Of the 37 isolates evaluated, seven showed anti-Listeria activity. The presence of
\end{abstract}


bacteriophages and production of acidic compounds were not detected. The selected antimicrobial compound was sensitive to proteinase $\mathrm{K}$ and the producing-bacterium was identified as Bacillus velezensis. The crude extract maintained the antimicrobial activity in different temperatures and $\mathrm{pH}$ conditions. In conclusion, the bacteriocin produced by Bacillus velezensis showed strong activity against Listeria monocytogenes, and great stability to elevated temperature and adverse $\mathrm{pH}$, desirable features for future biotechnological applications.

Keywords: Anti-Listeria activity; Bacteriocin; Bacillus.

\section{Resumo}

O objetivo deste trabalho foi investigar a produção de bacteriocinas com atividade anti-Listeria por bactérias naturalmente presentes na silagem e caracterizar a bacteriocina mais promissora. A produção de bacteriocinas foi avaliada pelo método de sobrecamada. A presença de fatores interferentes e a sensibilidade à proteinase $\mathrm{K}$ foram analisadas. O espectro de atividade foi determinado e o isolado produtor de bacteriocina mais promissor foi identificado, sendo selecionado para os experimentos subsequentes. O peptídeo antimicrobiano foi extraído, analisado quanto à sensibilidade à temperatura e ao pH, e purificado. Dos 37 isolados avaliados, sete apresentaram atividade anti-Listeria. Não foi detectada a presença de bacteriófagos e produção de compostos ácidos. O composto antimicrobiano selecionado foi sensível à proteinase $\mathrm{K}$ e a bactéria produtora foi identificada como Bacillus velezensis. O extrato bruto manteve a atividade antimicrobiana em diferentes temperaturas e condições de $\mathrm{pH}$. Em conclusão, a bacteriocina produzida por Bacillus velezensis apresentou elevada atividade contra Listeria monocytogenes, e grande estabilidade a temperatura elevada e pH adverso, características desejáveis para futuras aplicações biotecnológicas.

Palavras-chave: Atividade anti-Listeria; Bacteriocina; Bacillus.

\section{Resumen}

El objetivo de este trabajo fue investigar la producción de bacteriocinas con actividad anti-Listeria por bacterias presentes de forma natural en el ensilaje y caracterizar la bacteriocina más prometedora. La producción de bacteriocinas se evaluó mediante el método de superposición. Se analizó la presencia de factores interferentes y la sensibilidad a proteinasa K. Se determinó el espectro de actividad y se identificó el aislado productor de bacteriocina más prometedor, siendo seleccionado para experimentos posteriores. Se extrajo el péptido antimicrobiano, se analizó la sensibilidad a la temperatura y al pH y se purificó. De los 37 aislamientos evaluados, siete mostraron actividad antiListeria. No se detectó presencia de bacteriófagos ni producción de compuestos ácidos. El compuesto antimicrobiano seleccionado era sensible a la proteinasa $\mathrm{K}$ y la bacteria productora se identificó como Bacillus velezensis. El extracto crudo mantuvo su actividad antimicrobiana a diferentes temperaturas y condiciones de pH. En conclusión, la bacteriocina producida por Bacillus velezensis mostró alta actividad contra Listeria monocytogenes, y gran estabilidad a alta temperatura y $\mathrm{pH}$ adverso, características deseables para futuras aplicaciones biotecnológicas.

Palabras clave: Actividad anti-Listeria; Bacteriocina; Bacillus.

\section{Introduction}

Listeria monocytogenes is widely distributed in nature and can be found in soil, vegetation, water and intestinal tract of some animals (Reis et al., 2011). This pathogen is able to grow and adapt to different stress conditions, including a wide range of temperature $\left(1^{\circ} \mathrm{C}\right.$ to $\left.45^{\circ} \mathrm{C}\right)$, acidic $\mathrm{pH}$ and high salt concentration (Reis et al., 2011).

The infectious disease caused by L. monocytogenes is called listeriosis, and eating contaminated food containing this bacterium is the main route of infection (Junior et al., 2015). Listeriosis is one of the most serious and severe foodborne diseases, affecting livestock animals, especially ruminants, but also swine, poultry and fish, as well as humans. Although the number of cases of listeriosis is not so expressive, the high rate of death associated with this infection, especially among elderly and immunocompromised patients, makes it a significant public health concern (Reis et al., 2011; Buchanan et al., 2017; Heir et al., 2018).

Regarding the animal health, the consequences of listeriosis range from a decrease in animal production and milk quality, to encephalitis, abortion and infertility (Junior et al. 2015). One of the main sources of L. monocytogenes for ruminants is the consumption of silage contaminated with this bacterium. Although lactic acid bacteria usually dominate silage microbiota, some pathogens, including Listeria, can contaminate and grow during the ensilage, a process that includes fermentation and storage of silage. In this way, the consumption of low quality silage has been associated to listeriose cases in ruminants (Durmaz et al., 2015). 
As a diverse environment, with broad microbial diversity, the silage is a suitable environment for the isolation of bacteria that are able to produce antagonistic compounds (Castro et al., 2006), such as bacteriocins. Bacteriocins are ribosomally synthesized peptides, which show bactericidal or bacteriostatic activity against the target cells (Cotter et al., 2005; Drider et al., 2006; Todorov et al., 2010). Bacteriocin-producing strains have been proposed as an alternative for inhibiting spoilage microorganisms in silages, and could be used as effective inoculants to produce good quality and safe silages (Flythe and Russell, 2004; Amado et al., 2012).

The aim of this study was to investigate the production of anti-Listeria bacteriocins by naturally occurring bacteria on silage. The most promising bacteriocin was characterized and the producer cell was genetically identified.

\section{Methodology}

\section{Microorganisms and growth conditions}

Thirty seven bacteria, isolated from silage, and belonging to the culture collection of the Rumen Microbiology Laboratory, Embrapa Gado de Leite, Brazil, were randomly selected and screened for specific antagonism, in order to assess their usefulness in suppressing growth of L. monocytogenes. The isolates were maintained at $-80{ }^{\circ} \mathrm{C}$ in glycerol containing Brain Heart Infusion (BHI) medium (10\% final concentration), until use. The selected bacteria were grown in BHI medium, under aerobic conditions, at $37^{\circ} \mathrm{C}$.

\section{Screening of antagonistic activity against indicator bacteria}

Antagonistic activity was evaluated by the spot-on-lawn method (Booth et al. 1977). The silage bacteria were spotted onto BHI agar and incubated in aerobiosis, at $37{ }^{\circ} \mathrm{C}$, for $18 \mathrm{~h}$. Molten semi-solid BHI (0.8\% agar), previously inoculated with L. monocytogenes $\left(10^{5} \mathrm{CFU} \mathrm{mL}^{-1}\right)$, was poured over the agar plates containing the bacterial colonies. Plates were incubated at a suitable temperature and atmosphere for each indicator organism. The antimicrobial activity was determined by the presence of inhibition zones of the indicator organism growth around the colonies of selected bacteria ( $>6 \mathrm{~mm}$ diameter).

\section{Determination of interfering factors on the antagonistic activity}

In order to verify if the antagonistic activity observed on the spot-on-lawn method was indeed due to the production of antimicrobial peptides and not to the activity of other factors, we evaluated the presence of interfering factors, such as bacteriophage presence and production of acidic compounds by the selected silage isolates.

To evaluate the presence of bacteriophage, an agar piece $(3 \mathrm{~mm})$ of the inhibition zone observed in the spot-on-lawn method was aseptically removed, macerated in saline ( $\mathrm{NaCl} 0.9 \%, \mathrm{pH} \mathrm{7.0)}$, and centrifuged (12000 g, $20 \mathrm{~min})$. An aliquot of the supernatant $(200 \mu \mathrm{L})$ was transferred to a culture medium $(5 \mathrm{~mL})$, previously inoculated with the indicator microorganism. After incubation period (10 min, at room temperature), an aliquot of the culture medium containing the supernatant (350 $\mu \mathrm{L}$ ) was added to a semisolid BHI (3.5 mL), which was poured over a prior layer of solid BHI. After incubation in aerobiosis, at 37 ${ }^{\circ} \mathrm{C}$, the plates were evaluated regarding the presence of lytic zones, which would indicate the bacteriophage presence in the selected bacteria.

To exclude the possibility of the production of acidic compounds be responsible for the antagonism, after spot-onlawn experiment, the $\mathrm{pH}$ inside and outside of the growth inhibition zones were determined using $\mathrm{pH}$ measuring tapes.

\section{Spectrum of action of the antagonistic substances produced by silage bacteria}

The inhibitory activity of the antagonistic compounds was evaluated by the spot-on-lawn method (described above) using, as indicator microorganisms, different bacterial strains, including the culture collection strains Escherichia coli ATCC 
25922, Staphylococcus aureus ATCC 25923, Bacillus cereus ATCC 33018, Pseudomonas fluorescens NCTC 10038, Lactococcus lactis DPC 3147, Streptococcus salivarius 20P3, as well as Staphylococcus aureus, Streptococcus uberis, Streptococcus equinus, Pseudomonas sp., Escherichia coli and Klebsiella sp., all isolated from ruminants and belonging to the culture collection of the Rumen Microbiology Laboratory.

The plates were incubated in appropriate temperature and atmosphere for each indicator microorganism, for up to 48 h. The antimicrobial activity was verified by the presence of inhibition zones larger than $6 \mathrm{~mm}$ in diameter.

Based on the antimicrobial activity against $L$. monocytogenes and on the activity spectrum, the most promising silage bacterium was selected for the next experiments.

\section{Bacterial crude extracts with antimicrobial activity}

Extracts of the selected silage bacteria were obtained as described by Mantovani et al. (2002), with modifications. Briefly, the $\mathrm{pH}$ of the stationary phase bacterial cultures was adjusted to 6.5 , the cultures were heat treated $\left(70{ }^{\circ} \mathrm{C}, 30 \mathrm{~min}\right)$, and the cells were harvested by centrifugation $\left(4500 \mathrm{rpm}, 15 \mathrm{~min}, 5^{\circ} \mathrm{C}\right.$ ). The cell pellets were washed with sodium phosphate solution (5 mM, pH 6.5), centrifuged (4500 rpm, $15 \mathrm{~min}$ ), and resuspended in acidic calcium chloride solution (100 mM, pH 2.0). After this stage, the suspension was incubated at room temperature, under stirring, for $2 \mathrm{~h}$. At the end of the extraction step, the cell suspensions were centrifuged $\left(12500 \mathrm{rpm}, 20 \mathrm{~min}, 5{ }^{\circ} \mathrm{C}\right)$, and the cell free supernatant was lyophilized. The lyophilized material was resuspended in sodium phosphate solution $(5 \mathrm{mM}, \mathrm{pH} 6.5)$, and named "crude extract".

The antimicrobial activity of the crude extracts was assessed by agar well-diffusion assay (Tagg et al. 1976). Molten semi-solid BHI (0.8\% agar), previously inoculated with L. monocytogenes $\left(10^{7} \mathrm{CFU} \mathrm{mL}^{-1}\right)$, was poured onto sterile Petri dishes, and after solidification, $5 \mathrm{~mm}$ wells were drilled in the culture medium. The crude extracts were serially diluted in sodium phosphate solution ( $5 \mathrm{mM}, \mathrm{pH} 6.5)$, and applied $(20 \mu \mathrm{L})$ inside the wells. The plates were kept overnight at $4{ }^{\circ} \mathrm{C}$ (for diffusion of the antimicrobial compounds from the wells), and incubated in aerobiosis, at $37{ }^{\circ} \mathrm{C}$, for $24 \mathrm{~h}$. The antimicrobial activity was expressed as arbitrary units (AU), defined as the reciprocal of the highest dilution that showed an inhibition zone of at least $9 \mathrm{~mm}$ in diameter (Lewus and Montville, 1991).

\section{Proteinase K sensitivity of the crude extracts with antimicrobial activity}

In order to evaluate the peptide nature of the antimicrobial compounds produced by the selected silage bacteria, a proteinase $\mathrm{K}$ sensitivity assay was performed. BHI-containing plates, previously inoculated with L. monocytogenes, were used in an agar well-diffusion assay. Proteinase $\mathrm{K}\left(20 \mathrm{mg} \mathrm{mL}^{-1}\right)$ was added $(20 \mu \mathrm{L})$ next to each well in the culture medium; after $30 \mathrm{~min}$, the crude extracts $(20 \mu \mathrm{L})$ were applied inside the wells. The plates were kept overnight under refrigeration, and then aerobically incubated, at $37^{\circ} \mathrm{C}$, for $24 \mathrm{~h}$. Non-treated crude extracts were used as a positive control for antimicrobial activity. The proteinase $\mathrm{K}$ sensitivity was observed by alterations of the original inhibition halos, i.e., evidence of growth of the target organism where the proteinase $\mathrm{K}$ was added.

\section{Influence of temperature and $\mathrm{pH}$ on the biological activity of the crude extracts with antimicrobial activity}

The crude extracts with antimicrobial activity obtained from the silage bacterium were submitted to different treatments to evaluate their stability under variations of temperature and $\mathrm{pH}$.

In order to evaluate the thermal stability, aliquots of the crude extracts diluted in sodium phosphate solution $(5 \mathrm{mM}$, pH 6.5) were heated to $45^{\circ} \mathrm{C}, 60^{\circ} \mathrm{C}, 80^{\circ} \mathrm{C}$ and $100{ }^{\circ} \mathrm{C}$, for $30 \mathrm{~min}$. The antimicrobial activity of the crude extracts after heat treatment was evaluated by agar well-diffusion assay, using $L$. monocytogenes as indicator bacteria. Afterwards, the residual antimicrobial activity after heat treatment was compared with control samples of the crude extracts, which were kept 
refrigerated. The residual antimicrobial activity was calculated according to the following equation (Cladera-Oliveira et al. 2004):

$$
\mathrm{RA}(\%)=(\mathrm{HT} / \mathrm{CT}) \times 100
$$

Where RA is the residual antimicrobial activity, HT is the halo diameter $(\mathrm{mm})$ of L. monocytogenes growth inhibition obtained after heat treatment of the crude extracts (measured on the agar well-diffusion assay), and CT is the halo diameter (mm) of the control samples (non-treated crude extracts).

The Britton-Robinson buffer, composed by ortho phosphoric acid (0.04 M), acetic acid (0.04 M) and boric acid (0.04 M) was used to evaluate the stability of the crude extracts at different $\mathrm{pH}$ values $(2.0,4.0,8.0,10.0$ and 12.0). The $\mathrm{pH}$ adjustment was performed with $\mathrm{NaOH}$ solution $(2 \mathrm{M})$ and $\mathrm{HCl}(2 \mathrm{M})$, and the buffers were sterilized by filtration. The crude extracts with antimicrobial activity were diluted (1:2) in the buffer with the desired $\mathrm{pH}$, and the mixture was kept at room temperature, for $2 \mathrm{~h}$. The antimicrobial activity of the crude extracts was then evaluated on agar well-diffusion assay. Residual antimicrobial activity was determined as described above.

\section{Genetic identification of the selected silage bacterium}

The most promising silage bacterium was identified by 16S rRNA gene sequencing. Total DNA was extracted using the phenol-chloroform method with modifications (Oliveira et al. 2002) and measured by NanoDrop (Thermo Scientific). The 16S rRNA gene amplification reaction was performed in DNA thermal cycler GeneAmp PCR System 9700 (Applied Biosystems), using the pair of universal primers 27F (AGAGTTTGATCMTGGCTCA) and 1492R (TACGGYTACCTTGTTACGAC). The polymerase chain reaction (PCR) (25 $\mu \mathrm{L})$ was composed by $17.325 \mu \mathrm{L}$ milli-Q water, $2.5 \mu \mathrm{L} 10 \mathrm{X}$ buffer, $1.25 \mu \mathrm{L} \mathrm{MgCl}_{2}(50 \mathrm{mM}), 0.625 \mu \mathrm{L}$ dNTPs $(10 \mathrm{mM}), 1 \mu \mathrm{L}$ primer $\mathrm{F}\left(10 \mathrm{pM} \mu \mathrm{L}^{-1}\right), 1 \mu \mathrm{L}$ primer R $(10 \mathrm{pM}$ $\left.\mu \mathrm{L}^{-1}\right), 0.3 \mu \mathrm{L}$ Taq DNA Polymerase (5 U $\mu \mathrm{L}^{-1}$ ) (Thermo Scientific) and $1 \mu \mathrm{L}$ DNA $\left(50 \mathrm{ng} \mu \mathrm{L}^{-1}\right)$. The PCR conditions included an initial denaturation step at $95{ }^{\circ} \mathrm{C}$ for $5 \mathrm{~min}$, followed by 35 cycles of denaturation at $95{ }^{\circ} \mathrm{C}$ for $30 \mathrm{~s}$, annealing at $60{ }^{\circ} \mathrm{C}$ for $30 \mathrm{~s}$, and primer extension at $72{ }^{\circ} \mathrm{C}$ for $1 \mathrm{~min}$. The amplification cycle was followed by a final extension at $72{ }^{\circ} \mathrm{C}$ for $7 \mathrm{~min}$, and the tubes were kept at $4{ }^{\circ} \mathrm{C}$. The PCR products were analyzed by agarose gel electrophoresis (1.2\%), stained with ethidium bromide $\left(0.2 \mu \mathrm{g} \mathrm{mL}^{-1}\right)$ and visualized using UV transilluminator.

The amplicons were purified using Invisorb® Fragment CleanUp kit (Stratec Molecular), following the manufacturer instructions. The samples were quantified with NanoDrop and the sequencing was performed by the company Myleus Facility, using the chain termination method (Sanger Method), and the ABI3730 automated sequencer (Thermo Fisher Scientific). All consensus sequences obtained were compared to those available in GenBank database (National Center for Biotechnology Information - NCBI), and the alignment of the sequences was performed using the Basic Local Alignment Search Tool algorithm for nucleotide (BLASTn). The sequences obtained were deposited in GenBank database.

\section{Purification of the extract obtained from the selected silage bacterium}

The lyophilized extract containing the antimicrobial peptide was purified using Fast Protein Liquid Chromatography (FPLC). The extract was resuspended in $3 \mathrm{~mL}$ of water/trifluoroacetic acid (TFA) $0.045 \%$ (buffer A) and applied to a reversephase column (MonoCap C18 Fast-Flow column 0.1 x $150 \mathrm{~mm}$ - GL Sciences Inc., Japan) incorporated in NanoLC Proeminence system (Shimadzu, Kyoto, Japan) and equilibrated with $10 \%$ buffer B (acetonitrile/TFA $0.065 \%$ ). After a subsequent washing with 5 min of $10 \%$ buffer B, the fraction containing bacteriocin was eluted with a linear gradient ranging from 10 to $40 \%$ acetonitrile with $0.065 \%$ TFA for $25 \mathrm{~min}$; 40 to $80 \%$ for $10 \mathrm{~min}$; $80 \%$ for 10 min at a flow rate of $2 \mu \mathrm{L}$ min ${ }^{-1}$. 
The absorbance was monitored at $215 \mathrm{~nm}$. Eluted fractions were collected and tested regarding the anti-Listeria activity by the agar well-diffusion assay.

\section{Results}

From the 37 bacteria previously isolated from silage and selected to the evaluation of antagonist activity, seven isolates, defined as $111,117,120,129,135,139$, and 150, were capable to inhibit the growth of L. monocytogenes. Moreover, the presence of bacteriophages was not detected in the bacterial isolates, since no lysis plates were observed after culturing. The $\mathrm{pH}$ inside and outside of the growth inhibition halo was 7.0, confirming that the antagonist activity was not due the production of acidic compounds by the isolates.

Since the interference of bacteriophage presence and production of acidic metabolites on the inhibitory activity against L. monocytogenes were excluded, we evaluated the spectrum of activity of the antagonist compounds produced by the silage isolates. The majority of the indicator bacteria evaluated, including the Gram-negative strains, were inhibited in the spoton-lawn test, demonstrating the broad spectrum of action of the antagonist compounds produced by the silage bacteria (Table 1).

Table 1: Spectrum of action of the antagonist compounds produced by the silage isolates, using the spot-on-lawn method.

Indicator bacteria

S. aureus ATCC 25923

B. cereus ATCC 33018

P. fluorescens NCTC 10038

L. lactis DPC3147

S. salivarius $20 \mathrm{P} 3$

S. aureus

S. uberis

S. equinus

Pseudomonas sp.

E. coli

Klebsiella sp.
E. coli ATCC 25922

Silage isolates

\begin{tabular}{lllllll}
111 & 120 & 129 & 150 & 135 & 117 & 139 \\
\hline- & - & - & + & - & - & - \\
+ & + & + & + & + & - & + \\
+ & + & + & - & + & - & + \\
+ & - & + & + & + & - & - \\
- & + & - & - & + & - & - \\
+ & + & + & + & + & - & - \\
+ & + & - & + & - & + & + \\
+ & + & + & + & + & - & - \\
++ & +++ & - & + & - & - & +++ \\
+ & + & - & + & + & - & + \\
++ & + & - & + & - & + & + \\
+ & - & + & + & + & - & +
\end{tabular}

Antagonist activity: (-) absence of growth inhibition; presence of growth inhibition (+) inhibition zone/colony ratio between 1.04 and $1.80 ;(++)$ inhibition zone/colony ratio between 1.81 and $2.57 ;(+++)$ inhibition zone/colony ratio between 2.58 and 3.32. Source: Authors.

The antibacterial substances produced by the isolates 111 and 150 inhibited the growth of 10 indicator bacteria ( $83 \%)$, including the Gram-negative strains P. fluorescens NCTC 10038, and the environmental isolates Pseudomonas sp. and Klebsiella sp.. Other isolates, such as 117 , showed a more restricted spectrum of action, inhibiting the growth of only two of the bacterial indicators evaluated. Among the indicator bacteria evaluated, S. aureus ATCC 25923 was the most sensitive, being inhibited by the antagonistic compounds produced by the majority of the silage bacterial strains (except the isolate 117). On the other hand, E. coli ATCC 25922 was inhibited only by the antagonistic compound produced by the isolate 150. 
Based on the anti-Listeria activity and on the broader spectrum of action, the isolate 150 was selected for the subsequent experiments. The crude extract obtained from the isolate 150 showed strong anti-Listeria activity, and a zone of Listeria growth inhibition measuring $21 \mathrm{~mm}$ of diameter was observed in the agar well-diffusion assay (Figure 1). The crude extract obtained from the isolate 150 was sensitive to proteinase $\mathrm{K}$, losing its antagonist activity against L. monocytogenes after the treatment with the proteolytic enzyme. This effect was observed after changing in the form of the inhibition zone in the agar well-diffusion assay (Figure 2).

Figure 1: Inhibition activity of the crude extract obtained from the isolate 150 against Listeria monocytogenes. The agar welldiffusion assay was used.

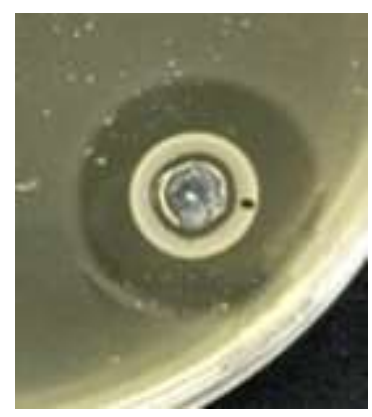

Source: Authors.

Figure 2: Sensitivity to proteinase $\mathrm{K}$ of the crude extract with antimicrobial activity obtained from the isolate 150 . Inhibition zones around the agar well are shown. A) Crude extract activity; B) Crude extract activity after proteinase K treatment. Listeria monocytogenes was used as indicator microorganisms in agar well-diffusion assay.

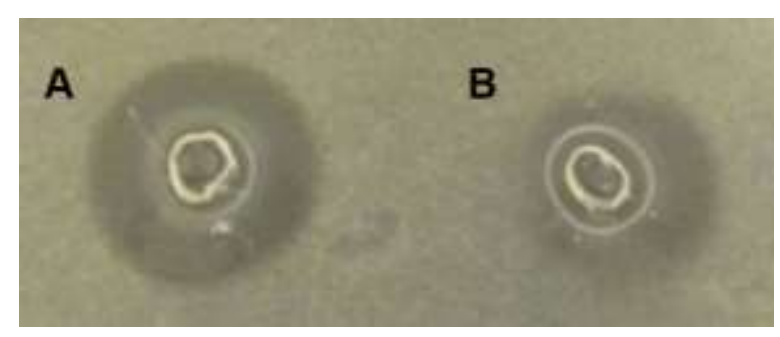

Source: Authors.

Once the peptide character has been confirmed by the protease $\mathrm{K}$ sensitivity, the antibacterial activity of the crude extract was determined in arbitrary units $\left(\mathrm{AU} \mathrm{mL} \mathrm{mL}^{-1}\right.$ ), being obtained an activity of $1600 \mathrm{AU} \mathrm{mL}^{-1}$ against L. monocytogenes (presence of Listeria-growth inhibition zones until the dilution 1:32) (Figure 3). 
Figure 3: Agar well-diffusion assay showing the inhibitory activity of the crude extract obtained from the isolate 150, using Listeria monocytogenes as indicator bacterium. From the crude extract, a serial dilution was prepared with twice increment (1:2 until 1:1024). Central well: crude extract; well 1: crude extract diluted 1:2; well 10: dilution 1:1024.

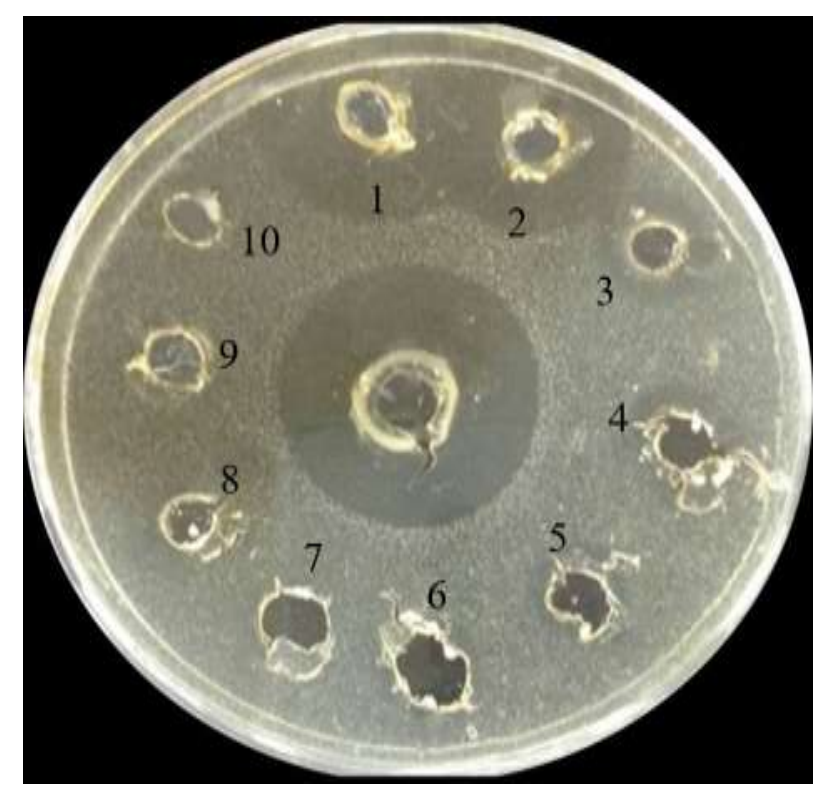

Source: Authors.

The crude extract obtained from the isolate 150 showed good stability in different temperatures, maintaining its antiListeria activity after heating and freezing (Fig. 4A). Considering the crude extract stored at $4{ }^{\circ} \mathrm{C}$ as a control (100\% of antiListeria activity), when the extract was submitted to $45^{\circ} \mathrm{C}$, the residual activity (RA) observed was $98 \%$; a RA of $93 \%$ was detected at $60{ }^{\circ} \mathrm{C}$, and at $80{ }^{\circ} \mathrm{C}$ the RA was $90 \%$. A bigger reduction in the anti-Listeria activity was observed when the crude extract was submitted to $100{ }^{\circ} \mathrm{C}(\mathrm{RA}=64 \%)$. The crude extract was also stable at lower temperatures, showing a $\mathrm{RA}$ of $92 \%$ and $97 \%$ when stored at $-20^{\circ} \mathrm{C}$ and $-80{ }^{\circ} \mathrm{C}$, respectively (Figure $4 \mathrm{~A}$ ).

Considering the $\mathrm{pH} 6.5$ as control (original $\mathrm{pH}$ of the extract), the growth inhibition zone for L. monocytogenes was determined as $28.4 \mathrm{~mm}$ (100\% antimicrobial activity). The crude extract showed a considerable stability in different pHs (Figure 4B). In all the pHs tested, the biological activity of the crude extract was more pronounced at $\mathrm{pH} 2(\mathrm{RA}>85 \%)$, and the residual activity remained over than $80 \%$ in the other $\mathrm{pH}$ values (4-12) (Figure 4B). 
Figure 4: Influence of the temperature and $\mathrm{pH}$ on the anti-Listeria activity of the crude extract obtained from the isolate 150, evaluated by the agar well-diffusion assay and graphed according to the residual antimicrobial activity. A) Thermal stability: (1) $4{ }^{\circ} \mathrm{C}$; (2) $45^{\circ} \mathrm{C}$; (3) $60{ }^{\circ} \mathrm{C}$; (4) $80{ }^{\circ} \mathrm{C}$; (5) $100{ }^{\circ} \mathrm{C}$; (6) $-20{ }^{\circ} \mathrm{C}$; (7) $-80{ }^{\circ} \mathrm{C}$. B) pH stability: (1) pH 2; (2) pH 4; (3) pH 8; (4) pH $10 ;(5) \mathrm{pH} 12$.

A
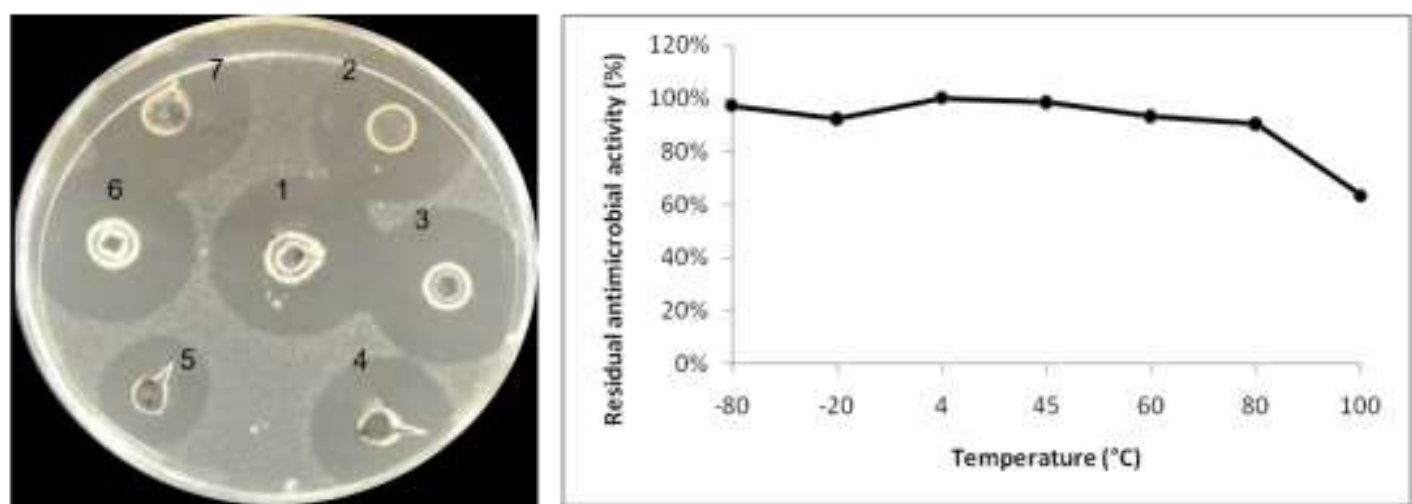

B
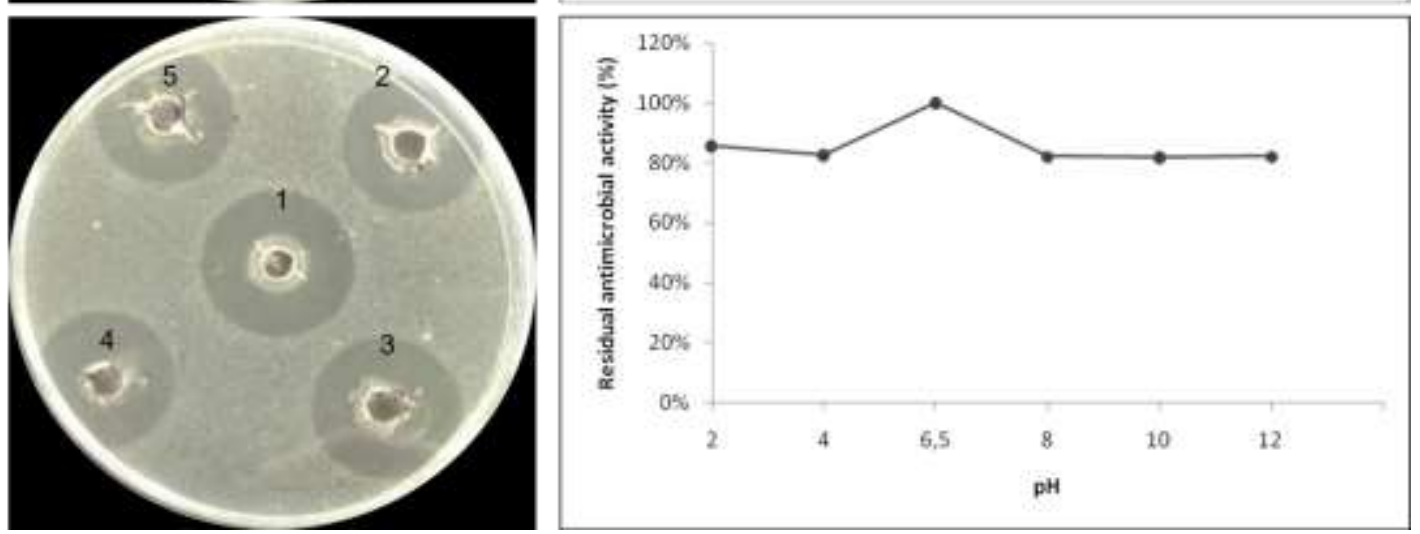

Source: Authors.

Analyses of similarity among the 16S rRNA gene sequence showed that the silage isolate evaluated showed high identity to Bacillus velezensis strain FZB42 (NR075005.2). The 16S rRNA gene sequence of the silage isolate (isolate 150) was deposited in the GenBank sequence database under accession number MK658866.

The crude extract obtained from B. velezensis (isolate 150) was purified in FPLC, using C18 column (Figure 5). The fractions were collected and the predominant peak, which appeared in the chromatogram after 7 minutes of purification, exhibited strong anti-Listeria activity, showing a halo of growth inhibition of $18 \mathrm{~mm}$ diameter in the agar well-diffusion assay (the crude extract before purification showed a zone of Listeria growth inhibition measuring 21 mm of diameter). The minor peaks observed in the chromatogram did not show antimicrobial activity. 
Figure 5: A fast protein liquid chromatogram of the crude extract obtained from Bacillus velezensis (isolate 150). The extract obtained from cells by acidic $\mathrm{CaCl}_{2}(100 \mathrm{mM}, \mathrm{pH}$ 2) was collected from a reverse-phase column (MonoCap C18 Fast-Flow column $0.1 \times 150 \mathrm{~mm}$ ) using trifluoroacetic acid $0.065 \%$ and a linear gradient of acetonitrile. The major peak obtained was tested and shows antimicrobial activity.

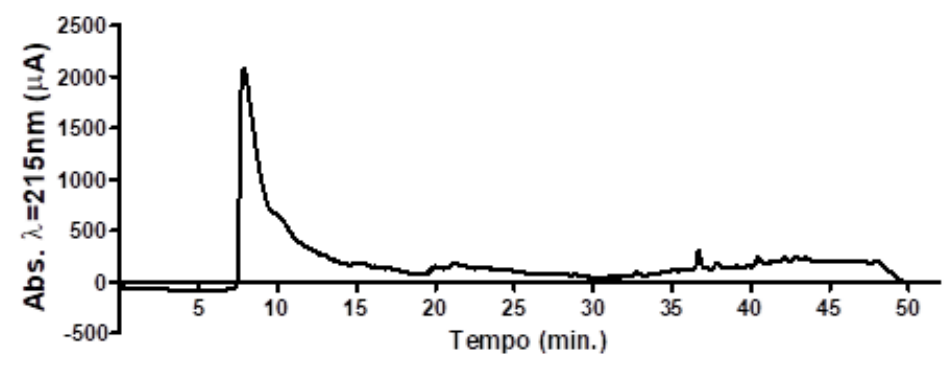

Source: Authors.

\section{Discussion}

Listeriosis can cause severe sequels to animal health. The clinical form of the disease can be characterized in three ways: septicemia, with abscesses in viscera, such as liver and spleen, abortion and meningoencephalitis (Campero et al., 2002). The acquisition of L. monocytogenes by animals can occur by the ingestion of water contaminated with feces or secretions of infected animals (Brugere-Picoux 2008), and, to ruminants, the main sources of this microorganism is soil and contaminated food (especially poorly fermented silage) (Fentahum and Freseberat, 2012).

Lactic acid bacteria (LAB) have been extensively used in order to inhibit the growth of undesirable microorganisms (Dolenčić Špehar et al., 2020). In addition to microbial control, LAB can also be used to improve the fermentation process in silage, contributing for silage quality (Cheng et al., 2021). Many of LAB are able to produce antimicrobial compounds, such as bacteriocins, that can control the bacterial community during the ensilage process (Contreras-Govea et al., 2011). The addition of Lactobacillus buchneri, a producer of the bacteriocin buchnericin LB, on sugarcane silage, for example, has been reported to inhibit the growth of undesirable bacteria, such as Listeria sp., Bacillus sp., Micrococcus sp., Enterococcus sp., Streptococcus sp., Lactobacillus sp., Leuconostoc sp. and Pediococcus sp., improving the quality of the silage and reducing the loss of dry matter during the ensilage process (Yildirim 2001; Zopollatto et al., 2009). However, these bacterial inoculants might not prevent secondary fermentation in moist silages, sometimes impairing the aerobic stability of grass and small grain silages (Weinberg and Muck, 1996). Therefore, it is important to evaluate other microorganisms than LAB as alternative inoculants to silage.

In the present study, $18.9 \%$ of the bacterial strains isolated from silage showed antibacterial activity, inhibiting the growth of L. monocytogenes, and other Gram-positive bacteria, including the pathogenic strains $S$. aureus and B. cereus, as well as Gram-negative bacteria, such as E. coli, Pseudomonas and Klebsiella. The activity spectrum of bacteriocins is generally associated to phylogenetically-related bacteria (Bordignon-Junior et al. 2013; Yang et al. 2014), although, as also demonstrated in the present study, some bacteriocins have shown a broad spectrum of action (Ivanova et al., 1998; Todorov et al., 2010; De Oliveira et al., 2012). It is important to highlight the activity of the bacteriocins produced by the silage isolates evaluated against $S$. aureus and E. coli, important pathogens that cause bovine mastitis, a disease still prevalent in the Brazilian herd that leads to considerable economic losses (Fagundes and Oliveira, 2004).

The most promising bacteriocin-producing bacterium evaluated in the present study was identified as B. velezensis. The genus Bacillus is a heterogeneous group of thermophilic Gram-positive endospore-forming bacteria, widespread in the environment, being the soil its main reservoir (Galvez et al., 1993). The production of bacteriocins have been reported in 
different strains of Bacillus, including cerein produced by B. cereus (Oscariz et al., 1999; Oscariz et al., 2006), bacillocin 490 by B. licheniformis (Martirani et al., 2002), thuricin by B. thuringiensis (Gray et al., 2006), haloduracin by B. halodurans (Lawton et al., 2007), and subtilosin by B. amyloliquifaciens (Sutyak et al., 2008). The peptides produced by Bacillus strains usually show a broader spectrum of activity (Abrioeul et al., 2011; Ansari et al., 2012). B. velezensis strain LS69, isolated from rice field, showed antagonist activity against several pathogens, including L. monocytogenes, and its genome sequencing reveals biosynthesis genes for the bacteriocins amylolysin and amylocycliclin (Liu et al., 2017). Another strain of B. velezensis (GF610), isolated from soil, produces the amyloliquecidin, with potent anti-Listeria activity (Gerst et al., 2017).

In this study, the protein character of the antibacterial compound produced by B. velezensis was confirmed by the proteinase $\mathrm{K}$ sensibility. The bacteriocin was stable to different wide of temperature and $\mathrm{pH}$, as expected for a bacterium capable of withstanding extreme environmental conditions (Abrioeul et al., 2011; Baruzzi et al. 2011; Ansari et al. 2012). The exposure of $B$. velezensis bacteriocin to low or high temperatures resulted in a slight reduction in its anti-Listeria activity. At temperatures below $80{ }^{\circ} \mathrm{C}$, the residual anti-Listeria activity remained above $90 \%$, while at $100{ }^{\circ} \mathrm{C}$ this activity decreased to $64 \%$. Lim et al., (2016) demonstrated similar results, being the residual activity of $100 \%$ when the bacteriocin produced by Bacillus amyloliquefaciens was exposed to $4{ }^{\circ} \mathrm{C}, 37^{\circ} \mathrm{C}, 50{ }^{\circ} \mathrm{C}$ and $80{ }^{\circ} \mathrm{C}$ for $30 \mathrm{~min}$, while in $100{ }^{\circ} \mathrm{C}$ this activity decreased to $80 \%$.

Even showing higher antimicrobial activity at neutral $\mathrm{pH}(\mathrm{pH}=6.5)$, the bacteriocin produced by B. velezensis showed considerable stability in different $\mathrm{pH}$ values, maintaining over than $80 \%$ of its anti-Listeria activity in the $\mathrm{pH}$ range of 2 to 12 . Similarly, stability to $\mathrm{pH}$ levels ranging from 3.0 to 9.0 was reported for mejucin, produced by Bacillus subtilis SN7 (Lee and Chang, 2018). On the other hand, a pH-dependent antimicrobial activity has been demonstrated for other bacteriocins, such as nisin, lactoestrepcin (Bromberg et al. 2006), and bovicin HC5 (Paiva et al., 2011). The stability of the bacteriocin prospected in our study to different $\mathrm{pH}$ and temperature value is important to its potential application.

\section{Final Considerations}

From the literature survey, it has been found that B. velezensis, a growing fast bacterium, is harmless to human and animal, and does not pollute the environment, playing an important role as a probiotic in animal feed. These properties, associated with the production of a broad inhibitory spectrum, $\mathrm{pH}$-tolerant and thermo-stable bacteriocin, characterized in our study, supports and suggests the use of B. velezensis and its bacteriocin as inoculants for silage, alone or in combination with other methods, specially focusing on L. monocytogenes proliferation control.

\section{References}

Abriouel, H., Franz, C. M., Omar, N. B., \& Gálvez, A. (2011). Diversity and applications of Bacillus bacteriocins. FEMS Microbiology Reviews, 35, 201-232.

Amado, I. R., Fuciños, C., Fajardo, P., Guerra, N. P., \& Pastrana, L. (2012). Evaluation of two bacteriocin-producing probiotic lactic acid bacteria as inoculants for controlling Listeria monocytogenes in grass and maize silages. Animal Feed Science and Technology, 175, $137-149$.

Ansari, A., Aman, A., Siddiqui, N. N., \& Iqbal, S. (2012). Bacteriocin (BAC-IB17): screening, isolation and production from Bacillus subtilis KIBGE IB-17. Pakistan Journal of Pharmaceutical Sciences, 25, 195-201.

Baruzzi, F., Quintieri, L., Morea, M., \& Caputo, L. (2011). Antimicrobial compounds produced by Bacillus spp. and applications in food. Science Against Microbial Pathogens: Communicating Current Research and Technological Advances, 2, 1102-1111.

Booth, S. J., Johnson, J. L., \& Wilkins, T. D. (1977). Bacteriocin production by strains of Bacteroides isolated from human feces and the role of these strains in the bacterial ecology of the colon. Antimicrobial Agents and Chemotherapy, 11, 718-724.

Bordignon-Junior, S. E., Miyaoka, M. F., da Luz Costa, J., Benavente, C. A. T., Couto, G. H., \& Soccol, C. R. (2013). Inhibiting Gram-negative bacteria growth in micro dilution by Nisin and EDTA treatment. Journal of Biotechnology and Biodiversity, 3, 127-135.

Bromberg, R., Moreno, I., Delboni, R. R., \& Cintra, H. C. (2006). Characterization of the bacteriocin produced by Lactococcus lactis ssp. hordniae CTC 484 and the effect of this compound on Listeria monocytogenes in beef. Food Science and Technology, 26, $135-144$. 
Brugere-Picoux, J. (2008). Ovine listeriosis. Small Ruminant Research, 76, 12-20.

Buchanan, R. L., Gorris, L. G. M., Hayman, M. M., Jackson, T. C., \& Whiting, R. C. (2017). A review of Listeria monocytogenes: An update on outbreaks, virulence, dose-response, ecology, and risk assessments. Food Control, 75, 1-13.

Campero, C. M., Odeón, A. C., Cipolla, A. L, Moore, D. P., Poso, M. A., \& Odriozola, E. (2002). Demonstration of Listeria monocytogenes by immunohistochemistry in formalin-fixed brain tissues from natural cases of ovine and bovine encephalitis. Journal of Veterinary Medicine, 49, $379-383$.

Castro, F. G. F., Nussio, L. G., Haddad, C. M., Campos, F. P., Coelho, R. M., Mari, L. J., \& Toledo, P. A. (2006). Perfil microbiológico, parâmetros físicos e estabilidade aeróbia de silagens de capimtifton 85 (Cynodon sp.) confeccionadas com distintas concentrações de matéria seca e aplicação de aditivos. Revista Brasileira de Zootecnia, 35, 358-71.

Cheng, Q., Li, P., Xiao, B., Yang, F., Li, D., Ge, G., Jia, Y., \& Bai, S. (2021). Effects of LAB inoculant and cellulase on the fermentation quality and chemical composition of forage soybean silage prepared with corn stover. Grassland Science, 67, 83-90.

Cladera-Olivera, F., Caron, G. R., \& Brandelli, A. (2004). Bacteriocin-like substance production by Bacillus licheniformis strain P40. Letters in Applied Microbiology, 38, 251-256.

Collins, F. W., O’Connor, P. M., O'Sullivan, O., Rea, M. C., Hill, C., \& Ross, R. P. (2016). Formicin - a novel broad-spectrum two-component lantibiotic produced by Bacillus paralicheniformis APC 1576. Microbiology, 162, 1662-1671.

Contreras-Govea, F. E., Muck, R. E., Mertens, D. R., \& Weimer, P. J. (2011). Microbial inoculant effects on silage and in vitro ruminal fermentation, and microbial biomass estimation for alfalfa, bmr corn, and corn silages. Animal Feed Science and Technology, 163, 2-10.

Cotter, P. D., Hill, C., \& Ross, R. P. (2005). Bacteriocins: developing innate immunity for food. Nature Reviews Microbiology, 3, $777-788$.

De Oliveira, C. P., de Siqueira Júnior, J. P., \& Da Silva, J. Á. (2012). Bacteriocinas como alternativa na conservação de alimentos. Revista Verde, 7, 09-15.

Dolenčić Špehar, I., Bendelja Ljoljić, D., Petanjek, Z., Zamberlin, Š., Tudor Kalit, M. \& Samaržija, D. (2020). Antimicrobial activity of bacteriocins of Lactic Acid Bacteria on Listeria monocytogenes, Staphylococcus aureus and Clostridium tyrobutyricum in cheese production. Mljekarstvo, 70, $135-149$.

Drider, D., Fimland, G., Héchard, Y., McMullen, L. M., \& Prévost, H. (2006). The continuing story of class IIa bacteriocins. Microbiology and Molecular Biology Reviews, 70, 564-82.

Durmaz, H., Avci, M., \& Aygün, O. (2015). The Presence of Listeria Species in Corn Silage and Raw Milk Produced in Southeast Region of Turkey. Kafkas Universitesi Veteriner Fakultesi Dergisi, 21, 41-44.

Fagundes, H., \& Oliveira, C. A. F. (2004). Infecções intramamárias causadas por Staphylococcus aureus e suas implicações em saúde pública. Ciência Rural, $34,1315-1320$.

Fentahun, T., \& Fresebehat, A. (2012). Listeriosis in small ruminants: a review. Advances Biological Research, 6, $202-209$.

Flythe, M. D., \& Russell, J. B. (2004). The effect of pH and a bacteriocin (bovicin HC5) on Clostridium sporogenes MD1, a bacterium that has the ability to degrade amino acids in ensiled plant materials. FEMS Microbiology Ecology, 47, 215-22.

Gálvez, A., Maqueda, M., Martínez-Bueno, M., Lebbadi, M., \& Valdivia, E. (1993). Isolation and physico-chemical characterization of an antifungal and antibacterial peptide produced by Bacillus licheniformis A12. Applied Microbiology and Biotechnology, 39, 438-442.

Gerst, M. M., Dudley, E. G., Xiaoli, L., \& Yousef, A. E. (2016). Draft genome sequence of Bacillus velezensis GF610, a producer of potent anti-Listeria agents. Genome Announcements, 5, e01046-17.

Gray, E. J., Lee, K. D., Souleimanov, A. M., Di Falco, M. R., Zhou, X., Ly, A., \& Smith, D. L. (2006). A novel bacteriocin, thuricin 17, produced by plant growth promoting rhizobacteria strain Bacillus thuringiensis NEB17: isolation and classification. Journal of Applied Microbiology, $100,545-554$.

Heir, E., Moretro, T., Simensen, A., \& Langsrud, S. (2018). Listeria monocytogenes strains show large variations in competitive growth in mixed culture biofilms and suspensions with bacteria from food processing environments. International Journal of Food Microbiology, 275 , 46-55.

Ivanova, I., Miteva, V., Stefanova, T. S., Pantev, A., Budakov, I., Danova, S., Moncheva, P., Nikolova, I., Dousset, X., \& Boyaval, P. (1998). Characterization of a bacteriocin produced by Streptococcus thermophilus 81. International Journal of Food Microbiology, 42, 147-158.

Junior, J. A. F., Nascimento, K. A., \& Miguel, M. P. (2015). Aborto e morte neonatal por listeriose em ruminantes. Investigação, $14,85-89$.

Lawton, E. M., Ross, R. P, Hill, C., \& Cotter, P. D. (2007). Two-peptide lantibiotics: a medical perspective. Mini reviews in Medicinal Chemistry, 7, 12361247 .

Lee, S. G., \& Chang, H. C. (2018). Purification and characterization of mejucin, a new bacteriocin produced by Bacillus subtilis SN7. LWT. Journal of Food Science and Technology, 87, 8-15.

Lewus, C. B., \& Montville, T. J. (1991). Detection of bacteriocins produced by lactic acid bacteria. Journal of Microbiological Methods, 13 , 145-50.

Lim, K. B., Balolong, M. P., Kim, S. H., Oh, J. K., Lee, J. Y., \& Kang, D. K. (2016). Isolation and characterization of a broad spectrum bacteriocin from Bacillus amyloliquefaciens RX7. BioMed Research International, 2016, 1-7.

Liu, G., Kong, Y., Fan, Y., Geng, C., Peng, D., \& Sun, M. (2017). Whole-genome sequencing of Bacillus velezensis LS69, a strain with a broad inhibitory spectrum against pathogenic bacteria. Journal of Biotechnology, 249, 20-24. 
Research, Society and Development, v. 10, n. 9, e2610917783, 2021

(CC BY 4.0) | ISSN 2525-3409 | DOI: http://dx.doi.org/10.33448/rsd-v10i9.17783

Mantovani, H. C., Hu, H., Worobo, R. W., \& Russell, J. B. (2002). Bovicin HC5, a bacteriocin from Streptococcus bovis HC5. Microbiology, 148, $3347-52$.

Martirani, L., Varcamonti, M., Naclerio, G., \& De Felice, M. (2002). Purification and partial characterization of bacillocin 490, a novel bacteriocin produced by a thermophilic strain of Bacillus licheniformis. Microbial Cell Factories, 1, 1-5.

Oliveira, S. D., Santos, L. R., Schuch, D. M. T., Silva, A. B., Salle, C. T. P., \& Canal, C. W. (2002). Detection and identification of salmonellas from poultryrelated samples by PCR. Veterinary Microbiology, 87, 25-35.

Oscáriz, J. C., Cintas, L., Holo, H., Lasa, Í, Nes, I. F., \& Pisabarro, A. G. (2006). Purification and sequencing of cerein 7B, a novel bacteriocin produced by Bacillus cereus Bc7. FEMS Microbiology Letters, 254, 108-115.

Oscáriz, J. C., Lasa, I., \& Pisabarro, A. G. (1999). Detection and characterization of cerein 7, a new bacteriocin produced by Bacillus cereus with a broad spectrum of activity. FEMS Microbiology Letters, 178, 337-341.

Paiva, A. D., Breukink, E., \& Mantovani, H. C. (2011). Role of lipid II and membrane thickness in the mechanism of action of the lantibiotic bovicin HC5. Antimicrobial Agents and Chemotherapy, 55, 5284-93.

Reis, C. M. F. D., Barbosa, A. V., Rusak, L. A., Vallim, D. C., \& Hofer, E. (2011). Antimicrobial susceptibilities of Listeria monocytogenes human strains isolated from 1970 to 2008 in Brazil. Revista da Sociedade Brasileira de Medicina Tropical, 44, 173-176.

Sutyak, K. E., Anderson, R. A., Dover, S. E., Feathergill, K. A., Aroutcheva, A. A., Faro, S., \& Chikindas, M. L. (2008). Spermicidal activity of the safe natural antimicrobial peptide subtilosin. Infectious Diseases in Obstetrics and Gynecology, 2008, 540758.

Tagg, J. R., Dajani, A. S., \& Wannamaker, L. W. (1976). Bacteriocins of Gram-positive bacteria. Bacteriological Reviews, 40, 722-756.

Todorov, S. D., Wachsman, M., Tomé, E., Dousset, X., Destro, M. T., Dicks, L. M. T., \& Drider, D. (2010). Characterization of an antiviral pediocin-like bacteriocin produced by Enterococcus faecium. Food Microbiology, 27, 869-79.

Weinberg, Z. G., \& Muck, R. E. (1996). New trends and opportunities in the development and use of inoculants for silage. FEMS Microbiology Reviews, 19, 53-68.

Yang, S. C., Lin, C. H., \& Fang, J. N. (2014). Antibacterial activities of bacteriocins: application in foods and pharmaceuticals. Frontiers in Microbiology, 5, $1-10$.

Yildirim, M. (2011). Purification of buchnericin LB produced by Lactobacillus buchneri LB. Turkish Journal of Biology, 25, 59-65.

Zopollatto, M., Daniel, J. L. P., \& Nussio, L. G. (2009). Aditivos microbiológicos em silagens no Brasil: revisão dos aspectos da ensilagem e do desempenho de animais. Revista Brasileira de Zootecnia, 38, 170-89. 